\title{
Krok ku rozwojowi wielokanałowej dystrybucji - omnichannel w praktyce
}

http://dx.doi.org/10.18778/8142-085-3.08

Aleksandra Janeczek, Zuzanna Nowak Katedra Systemów i Sterowania Ruchem Wydział Transportu, Politechnika Śląska

\section{Wstęp - czyli czym jest omnichannel}

Rozwijająca się technologia oraz szeroko pojęty przemysł prowadzą do szerszego rozumienia handlu, który jest nie tylko dystrybucją towarów, ale przede wszystkim formą kontaktu $\mathrm{z}$ klientem. Z każdym kolejnym krokiem świat technologii powoduje ewolucję dotychczasowych metod sprzedaży. Przedsiębiorcy zmuszeni są do przyjęcia dynamicznej postawy, by sprostać stale zmieniającym się oczekiwaniom klientów. W odpowiedzi na zapotrzebowanie powstał nowy trend marketingowy, jakim jest omnichannel (łac. omnis - wszystko). Mimo że trend ten nadal się kształtuje i ciężko go zdefiniować według określonych ram, zmienia on dotychczasowe podejście do zakupów jako redystrybucji dóbr, kierując je na nawiązywanie ciągłych relacji z klientem, który postrzegany jest zarówno jako osoba indywidualna, jak i jednostka biznesowa.

U podstaw strategii omnichannel leży konieczność towarzyszenia kupującemu na każdym etapie jego ścieżki zakupowej i w każdym kanale, tak aby proces ten był dla niego jak najbardziej satysfakcjonujący. Kluczowe jest zaprojektowanie rozwiązania w taki sposób, aby wspierać konsumenta już od pierwszej myśli o nowej potrzebie zakupowej, aż po finalne użytkowanie wyrobu (konsumpcję usługi).

Omnichannel marketing to spójna i przenikająca się komunikacja w wielu kanałach jednocześnie ${ }^{1}$. W praktyce oznacza to, że klient niezależnie od sposobu komunikowania się ze sprzedającym otrzymuje spójny zestaw informacji na temat oferty handlowej. Należy jednak zwrócić uwagę, że praktyczny omnichannel nie składa się wyłącznie z integracji kanałów sprzedaży, lecz z wszechstronnej formy dostępu do klienta, aby towarzyszyć mu ciągle w jego decyzjach zakupu. Dobro konsumenta i dbałość o zapewnienie mu jak najlepszych do-

1 http://nowymarketing.pl/a/10116,o-omnichannel-encyklopedia-marketingu [dostęp 06.04.2017]. 
świadczeń są najważniejsze w omnichannel. Strukturę sytemu tworzą między innymi: sklepy firmowe i partnerskie (placówki sprzedaży), magazyny wyrobów gotowych, platformy aukcyjne oraz systemy sieci komputerowych, zapewniających obsługę online.

\section{Czego oczekują klienci - czyli współczesny, świadomy klient}

Omnichannel powstał jako odpowiedź przedsiębiorców na zmieniające się nawyki zakupowe klientów. Konsumenci coraz częściej wykorzystują smartfony w procesie zakupów, również wtedy, gdy zakupy te odbywają się w sklepie stacjonarnym. Korzystają oni z możliwości przeglądania listy produktów, skanowania kodów kreskowych, by uzyskać informacje o towarze, jak i możliwości kierowania uwag bezpośrednio do producentów. Zamawiający nie chcą być w żaden sposób ograniczani; w trakcie dokonywania zakupu chcą mieć możliwość zmiany urządzenia mobilnego oraz swobodnego przemieszczania się. Coraz bardziej powszechne jest także tworzenie opinii o produktach i zamieszczanie ich w mediach społecznościowych oraz dokonywanie płatności za pomocą telefonu. Cały proces podjęcia decyzji o zakupie i jej realizacji został przedstawiony oraz omówiony na konkretnym przykładzie (zob. ilustr. 1).

Na skutek tak prostego i powszechnego dostępu do informacji znacznie wzrosła świadomość klienta, który obecnie prezentuje szereg konkretnych postaw i oczekiwań, takich jak: potrzeba szybkiej obsługi, chęć uzyskania kompleksowej informacji, dostęp do ofert konkurencyjnych, wiedzy na temat słabych i mocnych stron danego produktu, możliwość szybkiej zapłaty.

Dzisiejszy konsument ma świadomość relacji pomiędzy ceną a jakością. Podczas zakupów szuka możliwie najlepszej oferty za akceptowalną cenę, a dzięki dostępowi do Internetu może szybko porównać ceny konkurencyjnych sklepów oraz poznać opinie innych użytkowników na temat wybranego wyrobu. W tej sytuacji nieograniczony wybór produktów prowadzi do trudności w podjęciu właściwej decyzji zakupowej. Nabywca oczekuje szybkiej realizacji zamówienia oraz natychmiastowej reakcji na sygnalizowane przez niego potrzeby. Usytuowanie na dominującej pozycji w strategii zakupowej daje poczucie kontroli, co skutkuje zwiększeniem oczekiwań względem sprzedawcy, jak i poziomu obsługi klienta ${ }^{2}$.

2 http://marketerplus.pl/teksty/artykuly/kilka-slow-o-strategii-omnichannel/ [dostęp 06.04.2017]. 


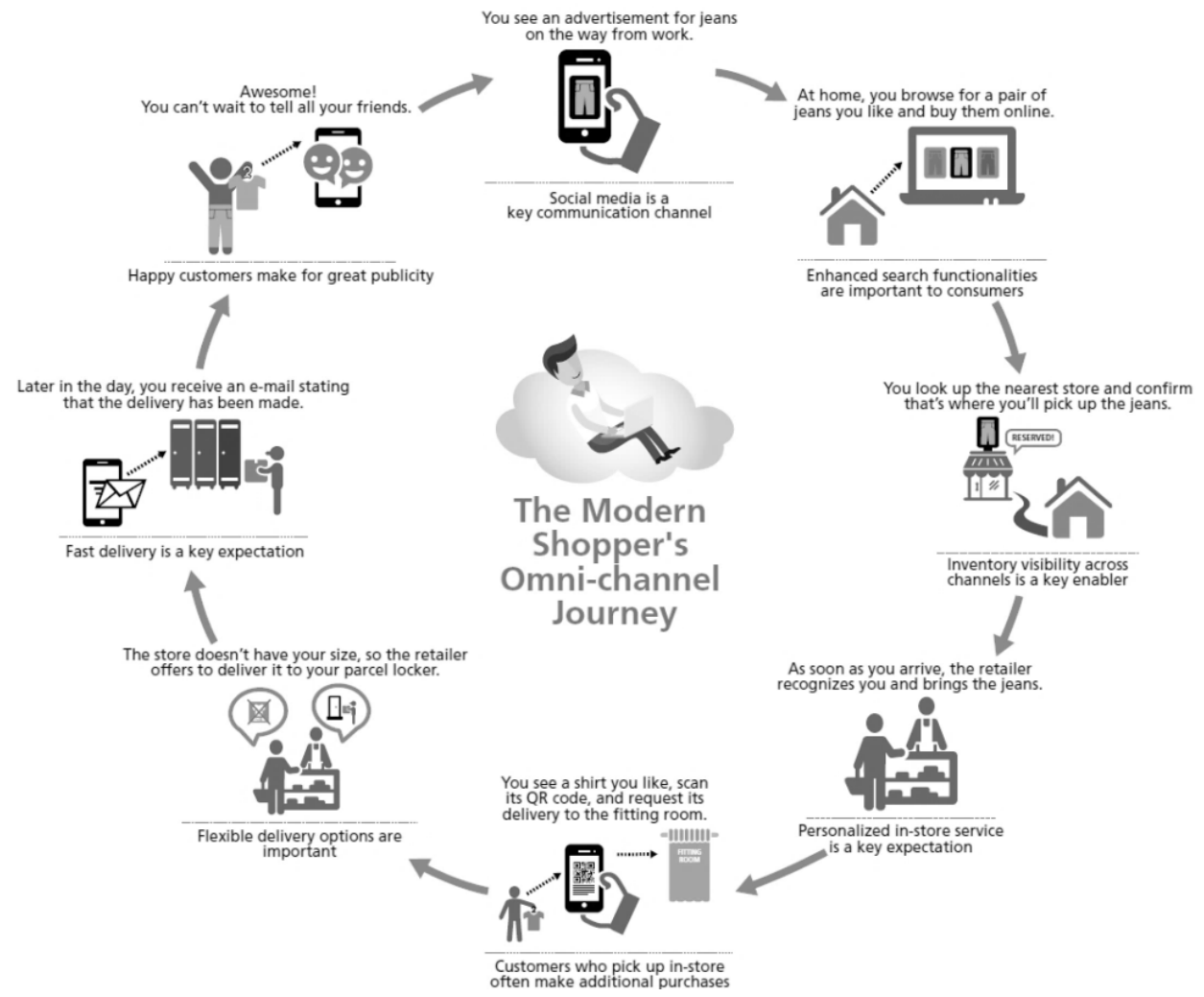

Ilustracja 1. Omnichannel w rzeczywistym procesie zakupowym współczesnego konsumenta

Źródło: http://www.dhl.com/content/dam/downloads/g0/about_us/logistics_insights/dhl_ trendreport_omnichannel.pdf/

Współczesny przedsiębiorca, który chce sprostać wymaganiom konsumenta, powinien prowadzić działania sprzedażowe w wielu kanałach jednocześnie, w postaci: salonów stacjonarnych, sklepów internetowych w wersji dostosowanej do wszystkich rodzajów urządzeń mobilnych, punktów contact center zarówno przez telefon, komunikatory, jak i livechat, aplikacji mobilnej służącej między innymi do weryfikacji dostępności produktów i ekspozycji asortymentu. Niezależnie od liczby punktów styku służących do komunikacji najważniejsza pozostaje ich integracja oraz spójność przedstawianych informacji, co stanowi szereg wyzwań logistycznych omówionych szerzej w następnych częściach pracy.

Wszechkanałowość bazuje na zbieraniu wiedzy o konsumencie, zarówno twardej (jak adresy e-mail, płeć, wiek), jak również miękkiej (analizy zachowań użytkowników online i offline, np. czas spędzony na przeglądaniu ofert). Daje to możliwość bliższego poznania klienta oraz trafnego i skutecznego komunikowania się z nim. Znając powód kupna konkretnego produktu, łatwiej będzie odpowiedzieć 
na kolejno pojawiające się potrzeby. Pozwala to ograniczyć niepożądany przekaz na rzecz trafionych i spersonalizowanych komunikatów, kierowanych wyłącznie do zainteresowanych osób. Możliwe jest wówczas bliższe poznanie klienta, jak również trafna i skuteczna komunikacja. To daje podstawy do odpowiedzi na pytanie, dlaczego klienci kupują produkty danej marki. Znajomość nowych potrzeb konsumentów umożliwia dynamiczną reakcję ze strony producentów.

\section{Jak sprostać omnichannel - wymagania stawiane przedsiębiorcom}

Działania składające się na omnichannel to nie tylko te internetowe, ale również realizowane w sklepach stacjonarnych, a także szeroko pojętym zapleczu logistycznym. Te ostatnie, choć często pomijane i niezauważane przez odbiorców, odgrywają niezwykle istotną rolę, szczególnie w e-commerce. Logistyka jest branżą mającą kluczową rolę w procesie wdrażania modelu omnichannel.

Aby uzyskać skuteczny i długotrwały efekt, należy zacząć wprowadzanie innowacji od fundamentów, czyli od inwestowania w spójny system zarządzania łańcuchem dostaw, który umożliwi pełną przejrzystość zapasów we wszystkich kanałach. Integracja wszystkich elementów na drodze produktu czy usługi (do klienta) to pierwszy krok do wprowadzenia strategii omnichannel i wykorzystania w pełni jej potencjału.

Jednym z największych wyzwań logistycznych przy obsłudze firm prowadzących sprzedaż w modelu omnichannel jest różna forma przepływu towarów - inna dla detalu i hurtu oraz dla sprzedaży internetowej i przez tradycyjne sieci handlowe. Magazyn realizuje zlecenia zarówno pełnopaletowe (hurt), jak i na pojedyncze sztuki (e-commerce) ${ }^{3}$. Symultanicznie, po przeciwnej stronie łańcucha konsumenci generują strumienie wejściowe niebędące zakupami, czyli zwroty, ze skomplikowaną procedurą obsługi. Traktując obsługę klienta całościowo, warto skupić uwagę na elementach najbardziej widocznych i istotnych z punktu widzenia kupującego. Te czynniki mogą okazać się kluczowe przy podjęciu ostatecznej decyzji zakupu. Są to:

- niski koszt dostawy - to drugi po atrakcyjnej cenie produktu czynnik decydujący o tym, czy klient skorzysta z oferty;

- wygodne opcje przesyłki - czyli najbardziej dostosowane do chwilowych potrzeb klientów. Warto zwrócić uwagę, że ta sama osoba w różnych oko-

3 https://retailnet.pl/2015/12/22/15069-logisys-efektywna-logistyka-przy-sprzedazy-omni channel/ [dostęp 06.04.2017]. 
licznościach może mieć różne potrzeby. Szeroka gama możliwości (np. dostawa kurierska, przesyłka pocztowa, paczkomat czy odbiór osobisty w wyznaczonym miejscu) pozwala dotrzeć do większego grona odbiorców;

- pełny zakres usług przed- i posprzedażowych, w tym zwrotów - prosta procedura zwrotu jest najbardziej pożądanym i brakującym ogniwem w obszarze działań logistycznych. Obawa większości konsumentów przed źle dokonanym wyborem, a w konsekwencji koniecznością przejścia kłopotliwej procedury, by zwrócić niechciany towar, odstrasza wielu potencjalnych klientów. Innowacyjnym rozwiązaniem, które warto wdrażać, jest organizacja darmowej wysyłki produktu w przypadku zwrotu bądź możliwość wymiany towaru w sklepie stacjonarnym. Jest to obecnie rozwiązanie mało popularne, jednak warte wdrażania, z sukcesem realizowane przez firmy z branży odzieżowej i obuwniczej.

Istotne jest także globalne spojrzenie na jakość dostawy. Terminowość oraz to, jakie wrażenie pozostawi po sobie kurier, są kluczowymi elementami decydującymi o tym, jaką opinię o e-sklepie będzie miał klient. Wyzwanie „ostatniej mili”, czyli komfort klienta przy odbiorze przesyłki oraz możliwość jej monitorowania przez cały okres dostawy, jest aspektem, na który coraz częściej zwraca się uwagę. Odbiorca produktu musi mieć wrażenie, że ma bieżącą kontrolę nad swoim zamówieniem. Oczekuje wiedzy na temat przesyłki w czasie rzeczywistym (śledzenie ścieżki realizacji zamówienia), a spełnienie jego wymagań zapewnia zintegrowane wsparcie systemowe.

Nowoczesną odpowiedzią na logistyczne potrzeby i trudności wynikające z uruchamiania kanału e-commerce jest tzw. filozofia Fulfilment Factory. Ten kierunek działania wskazuje na przekształcenie systemu oraz rozbudowę dotychczasowej infrastruktury w celu efektywnej obsługi wszechkanałowej w taki sposób, by możliwa była obsługa rożnych dróg wysyłkowych jednocześnie. Zastosowana automatyka magazynowa daje pełną kontrolę nad procesami, umożliwia realizację wielu zleceń i skutecznie eliminuje błędy wynikające z czynnika ludzkiego w przypadku, gdy wskutek e-commerce następuje rozdrobnienie zamówień oraz wzrost liczby asortymentu.

Właściwie zaprojektowany proces logistyczny (dopasowany do struktury), który nie generuje błędów i wytwarza optymalnie niski koszt jednego zlecenia czy zwrotu, stanowi podstawę operacyjnej wydajności biznesu. W tych dużych i kosztownych inwestycjach nie ma miejsca na błędy na etapie planowania, ponieważ skutkują one brakiem zamierzonych efektów oraz koniecznością ponoszenia kolejnych kosztów, związanych z działaniami naprawczymi. Kluczowe jest precyzyjne przygotowanie inwestycji w automatykę, gdzie punktem wyjścia będzie optymalny projekt procesów.

Usługi logistyczne są siłą napędową, bez których trend omnichannel nie mógłby się rozwijać. W tej strategii innowacje powinny być wdrażane na każdym etapie procesu sprzedażowego, począwszy od zmian w magazynie, przez zmiany w łańcuchach dostaw, modyfikację wizji firmy, a w efekcie przemyślane podejście do klienta, które widoczne jest w końcowym etapie sprzedaży. 


\section{Co stoi na drodze omnichannel - bariery we wdrażaniu strategii}

Skuteczne wdrożenie strategii omnichannel jest trudniejsze dla przedsiębiorców w porównaniu z innymi koncepcjami marketingowymi pojawiającymi się na rynku. Sama nazwa omnichannel jest zapowiedzią niekończących się wyzwań: wszystko, co dziś jest dużym osiągnięciem, jutro będzie zaledwie standardem. Wielopłaszczyznowe podejście do pojawiających się problemów i szerokie postrzeganie rynku ułatwia skomplikowany proces wdrażania innowacji w przedsiębiorstwie.

Wprowadzanie kolejnych elementów wszechkanałowości wymaga różnych rozwiązań strategicznych, wdrażanych w zależności od rozmiaru i zasięgu działania firmy. To właśnie te cechy warunkują strukturę organizacyjną firmy, co pociąga za sobą sposób wdrażania rozwiązań. Wprowadzenie dobrze działającej strategii omnichannel wymaga pokonania barier, takich jak:

- zmiany w strukturze organizacyjnej firmy,

- zastosowanie nowoczesnych technologii,

- wdrożenie rozwiązań automatycznych.

W dużej organizacji poszczególne działy często rozwijają rozwiązania sprzedażowe niezależnie od siebie. Oznacza to, że każda komórka organizacyjna ma inny zakres obowiązków niewymagających wewnętrznej współpracy. Przy dużej skali organizacji taki podział ról jest naturalny, jednak brak wspólnej strategii, ukierunkowanej na potrzeby konsumenta w procesie zakupowym, osłabia skuteczność wszystkich działań przepływowych. Wdrażanie omnichannel wymaga kooperacji w obszarach logistycznym, sprzedażowym oraz marketingowym. W małych przedsiębiorstwach realizacja działań związanych z obsługą klienta skupiona jest w rękach mniejszej grupy pracowników. Ułatwia to współpracę oraz opracowanie przejrzystego planu marketingowego.

Integracja kanałów komunikacji z klientem wymaga inwestowania w technologię, która pozwoli analizować historię zakupów, budować adekwatne komunikaty reklamowe i gromadzić wiedzę o działaniach klienta. Jest to pierwszy i najważniejszy krok decydujący o sukcesie wdrożenia strategii wszechkanałowości.

Wdrożenie nowoczesnych technologii nieodzownie łączy się z automatyzacją zarówno w obszarze analizy danych, jak i zmian infrastruktury logistycznej. Automatyzacja działającego systemu, który analizuje wiele kanałów, wymaga danych oraz przetworzenia ich w taki sposób, by uzyskać informacje o skuteczności zastosowanej strategii sprzedaży. Potrzebne dane klienci zostawiają nieświadomie poprzez: korzystanie $\mathrm{z}$ aplikacji mobilnych, logowanie się do różnych platform, przeglądanie Internetu, zapisanie się do newsletterów oraz programów lojalnościowych. Wyselekcjonowanie ich, zebranie, zestawianie ze sobą oraz wnioskowanie $\mathrm{w}$ modelu przenikania się kanałów nie jest proste. Podmioty związane z e-commerce sięgają po systemy statystycznego modelowania umożliwiające po- 
równanie obecnych i historycznych danych, by lepiej przygotować się do tego, co może się wydarzyć w przyszłości, budując wzorce zachowań i określając trendy ryzyka (poprzez analizę danych odnośnie do: stanów magazynowych, płatności, marketingu, zwrotów, zamówień oraz zapotrzebowania). Algorytmy statystyczne są częścią strategii działania.

Automatyzacja to konieczność we wszechkanałowości, jednak niesie ze sobą ryzyko. Zagrożeniem, jakie wynika z zakupu zaawansowanej automatyki, jest nieprawidłowe skonfigurowanie wyposażenia, w wyniku którego traci się na efektywności. Skutkuje to niewykorzystaniem pełnych możliwości technologii i pojawieniem się błędów. Złe oszacowanie zapotrzebowania na wprowadzanie automatyzacji wiąże się ze wzrostem kosztów. Niewystarczająco rozbudowany system nie sprosta stawianym mu oczekiwaniom, a pracując $\mathrm{w}$ stanie przeciążenia, będzie nieefektywny. Inne ryzyko wiąże się z kolei z przeszacowaniem potrzeb i możliwości właściwego zagospodarowania sprzętu, co skutkuje zwiększeniem kosztów eksploatacyjnych. Rozwiązaniem będzie skorzystanie z usług niezależnego eksperta, którego podejście skoncentruje się wyłącznie na procesach i wartości, jakie logistyka powinna dostarczać biznesowi ${ }^{4}$.

Wprowadzenie skutecznego funkcjonowania strategii jest procesem skomplikowanym i złożonym. Pomimo że około jednej trzeciej branży podjęło już działania związane z obszarami omnichannel, to większość zatrzymała się w połowie drogi. Wprowadzone dotychczas zmiany nie są wystarczające w procesie ciągłego doskonalenia działania firmy. Nawet jeśli w chwili zakończenia projektu wydawało się, że wdrożona wizja jest kompletna, to świat zmieniający się każdego dnia już unieważnił tę hipotezę.

\section{Gdzie wdrożono wszechkanałowość - omnichannel w praktyce}

Obecność zarówno stacjonarnych, jak i internetowych sklepów już na stałe wpisała się w krajobraz polskiego handlu. Przedsiębiorca, chcąc dostosować swoją ofertę do wymogów rynku, jest zobligowany do integracji kanałów, w których prowadzi komunikację ${ }^{6}$.

4 https://retailnet.pl/2015/05/28/12660-trzy-przeszkody-na-drodze-do-omnichannel-czywarto-pokonywac-je-samemu/ [dostęp 06.04.2017].

5 Tamże.

6 http://www.benchmark.pl/testy_i_recenzje/omnichannel-nadzieja-na-konkurencyjnoschandlu-detalicznego. html/ [dostęp 06.04.2017]. 
Wszystkie firmy, które chcą zachować konkurencyjność na polskim rynku, zaczęły wprowadzać strategię omnichannel. Złożoność tego procesu wymaga etapowej realizacji, co w zależności od stadium wdrożonych rozwiązań warunkuje pozycję firmy na rynku. Przykładami firm, które dobrze zapoczątkowały zmiany w swojej wizji i dzięki temu osiągają coraz większy sukces, są sieci sklepów Gino Rossi i EURO. Niestety, potrzeby konsumentów (szczególnie młodego pokolenia) są nadal wyraźnie większe niż oferta w zakresie wirtualnej, zintegrowanej obsługi ze strony przedsiębiorstw. Powodem, dla którego trend nie jest wyraźnie widoczny w naszym kraju, jest struktura rynku, na którym 90\% stanowią małe e-przedsiębiorstwa ${ }^{7}$.

Popularyzacja modelu omnichannel oznacza wejście w sprzedaż online dla przedsiębiorstw świadczących standardowe usługi, jak również wyjście sklepów online $\mathrm{z}$ Internetu do klienta w punkcie stacjonarnym.

Przykłady firm, które w kreatywny sposób podeszły do wszechkanałowości i wypracowały ciekawe rozwiązania, to:

- sieć Tesco w Korei Południowej,

- Google,

- House of Fraser,

- Zalando,

- Starbucks.

Sieć Tesco w Korei Południowej stworzyła wirtualne wystawy sklepowe w metrze, gdzie za pomocą kodów QR można zamówić towar z dostawą pod konkretny adres. Wirtualne półki połączyły świat zakupów online i offline (zob. ilustr. 2). Wygląd i forma prezentacji produktów są niemal identyczne jak w sklepie stacjonarnym, jednak oczekiwanie na bezpośrednią dostawę do domu kojarzy się z zakupami w sieci ${ }^{8}$.

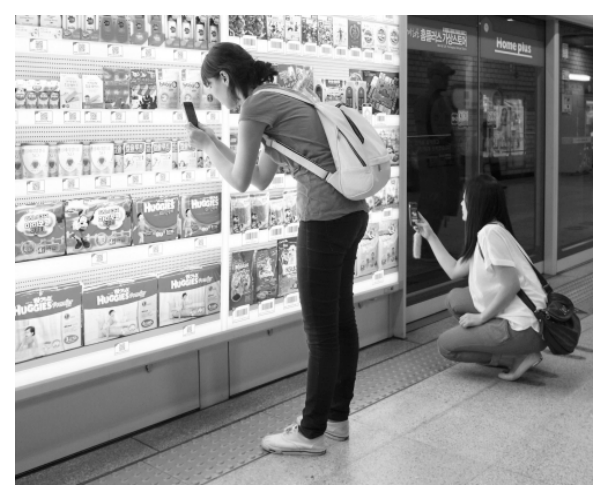

Ilustracja 2. Wirtualna wystawa sklepowa sieci Tesco w Korei Południowej

Źródło: http://www.getmemedia.com/public/ideas/Opp/12940/homeplus-5.jpg

7 https://www.pb.pl/co-to-jest-omnichannel-770599/ [dostęp 06.04.2017].

8 http://di.com.pl/wirtualne-sklepy-tesco-w-korei-poludniowej-3999/ [dostęp 06.04.2017]. 
Sklep stacjonarny firmy Google „Google shop” jest przeciwieństwem dotychczas pojmowanego dążenia do wszechkanałowości9. Podczas gdy wszystkie przedsiębiorstwa szukają rozwiązań w obszarze online, Google wkracza w nowy dla siebie obszar sklepów stacjonarnych, w których daje możliwość testowania sprzętu oraz dąży do fizycznego kontaktu z klientem (zob. ilustr. 3).

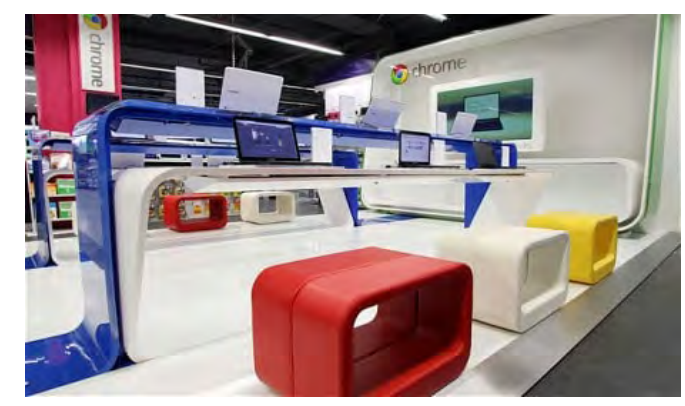

Ilustracja 3. Sklep stacjonarny firmy Google w Londynie

Źródło: http://i.telegraph.co.uk/multimedia/archive/02014/GD_Google0335_2014438c.jpg

Brytyjska marka House of Fraser wyposażyła manekiny w swoim stacjonarnym sklepie w małe nadajniki Bluetooth (beacony) wysyłające powiadomienia do osób, które zainstalowały dedykowaną aplikację i znajdują się w pobliżu sklepu ${ }^{10}$. Dzięki temu potencjalni klienci mogą dowiedzieć się o nowej ofercie bezpośrednio i w nieinwazyjny sposób. Ponadto w sklepach znajdują się elektroniczne przymierzalnie, gdzie przy użyciu swojego zdjęcia można stworzyć swoją wirtualną stylizację (zob. ilustr. 4).

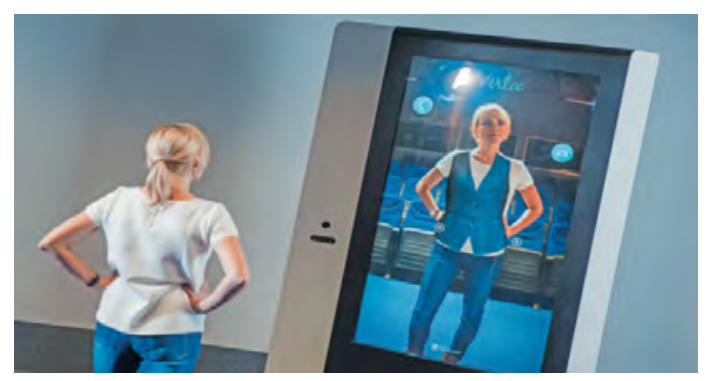

Ilustracja 4. Wirtualne lustra w sklepie House of Fraser Źródto: http://www.forbes.pl/g/i.aspx/0/500/forbes/635563962490714109.png

9 http://www.spidersweb.pl/2015/04/sklep-google-londyn.html/ [dostęp 06.04.2017].

10 http://retailnet.pl/2014/08/13/8506-wielka-brytania-interaktywne-manekiny-w-sklepachczolowej-marki-odziezowej/ [dostęp 06.04.2017]. 
Zalando jest firmą, która szeroko wykorzystuje ideę omnichannel w wielu aspektach swojej działalności. Przyjęła ona postawę prokliencką, oferując serwis składający się z bezpłatnych przesyłek i zwrotów, bezpłatnej infolinii oraz możliwości zwrotu wszystkich produktów rozszerzonej na okres stu dni. Otwarty został również sklep stacjonarny (pop-up store), w którym organizowane są wydarzenia związane z branżą fashion \& beauty ${ }^{11}$.

Starbucks, jako sieć międzynarodowa, wprowadził możliwość dokonywania zamówień oraz płatności przez dedykowaną aplikację, by docelowo przekształcić ją w mobilny program lojalnościowy (zob. ilustr. 5). W samej Wielkiej Brytanii z programu „My Starbucks Reward” korzystają 2 miliony konsumentów ${ }^{12}$.

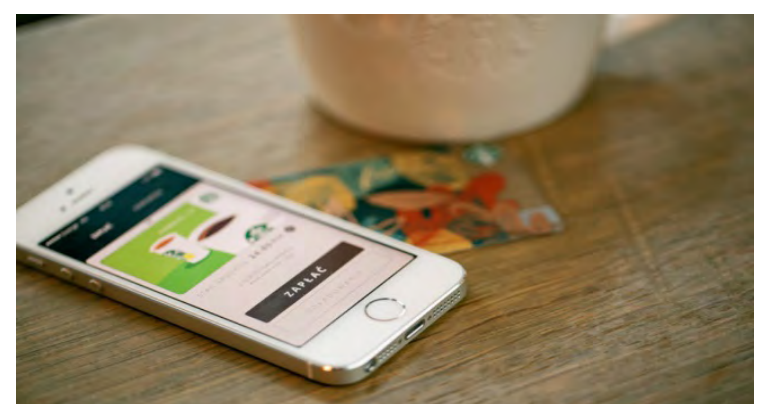

Ilustracja 5. Dedykowana aplikacja firmy Starbucks

Źródło: http://businesstraveller.pl/wp-content/uploads/2015/12/Starbucks_App5_860x573.jpg

Oryginalne przykłady rozwiązań omnichannel są drogowskazem dla innych przedsiębiorstw. $Z$ dużym powodzeniem strategię omnichannel zaczynają wprowadzać inne znane marki, szczególnie z branży AGD i RTV, takie jak: Euronet i Media Saturn. Duży sukces osiągnęły także firmy działające na rynku fashion \& beauty: Deichmann, Douglas, Sizeer czy Zara. Sieci sklepów z branży DIY, takie jak Jula czy Leroy Merlin, konsekwentnie stawiają na technologie wspierające spójne doświadczenia zakupowe.

Wszystkie wyżej wymienione firmy zyskały przewagę nad konkurencją dzięki oferowanym ułatwieniom. Czynnik mający wpływ na lojalność klientów to minimalizacja wysiłku wymaganego w zetknięciu się z organizacją podczas kupna, reklamacji, odbioru czy zwrotu. Jest to łatwość w kontakcie z marką w dowolnie wybranym kanale, która sprawia, że klienci pozostają w stałych stosunkach z marką.

11 https://retailnet.pl/2014/10/27/98094-zalando-otwiera-pierwszy-pop-store-w-polsce/ [dostęp 06.04.2017].

12 http://gomobi.pl/news/sprzedawco-wdrazaj-w-modelu-omnichannel-strategie-iprzyklady/ [dostęp 06.04.2017]. 


\section{Jak przedstawia się użyteczność - omnichannel w danych statystycznych}

Dla przedsiębiorców, którzy chcą osiągnąć standardy światowej obsługi i sprostać wymogom wyznaczanym przez konkurencję, wdrożenie strategii omnichannel jest koniecznością, a nie jedynie obligatoryjną możliwością. Usługodawcy zmuszeni są zmierzyć się z wyzwaniem, jak zostać zauważonym przez klientów, którzy mają nieograniczony dostęp do produktów w Internecie. Nie wystarczy już tylko sprzedawać wyroby, lecz trzeba zaoferować wartość dodaną inną niż cechy materialne (użytkowe) towaru, ponieważ klientom zależy na tym, by zyskać coś więcej niż tylko produkt, na przykład choćby komfort i szybkość obsługi.

Efektywne wdrażanie strategii omnichannel nieodłącznie powiązane jest z położeniem nacisku na e-commerce. $\mathrm{Z}$ ubiegłorocznych danych wynika, że liczba aktywnie kupujących w sieci wynosi $20 \%$ wszystkich klientów ${ }^{13}$. Dla sklepów internetowych jest to ogromny potencjał. $Z$ analizy stu najpopularniejszych sprzedawców w Polsce wynika, że aż 66\% z nich oferuje swoim klientom możliwość zakupów na urządzeniach mobilnych (w postaci strony internetowej bądź aplikacji).

Wydaje się, że polskie przedsiębiorstwa rozumieją panujący obecnie trend i podążają w dobrym kierunku. Już 13\% polskich sklepów posiada własną aplikację mobilną. Należy jednak pamiętać o tym, że jest to rozwiązanie wyłącznie dla stałych klientów, którzy często dokonują zakupów w konkretnym sklepie, natomiast nie jest to dobra droga do pozyskania nowych klientów.

Z danych statystycznych wynika, że obecnie 93\% firm wybiera więcej niż jeden kanał dotarcia do potencjalnych klientów. W blisko połowie przypadków - 47\% sprzedawców - decyduje się na dwa inne kanały, podczas gdy aż cztery różne rodzaje obsługi klienta oferuje $46 \% \mathrm{z}$ nich. Jedynie $3 \%$ uwzględnionych w analizie ogranicza kontakt z klientem do jednego kanału, którym najczęściej jest e-mail. Dzięki niskim kosztom i jednoczesnemu zachowaniu wysokiej efektywności jest on wciąż wiodącym kanałem komunikacji. Łatwo go wdrożyć, a dodatkowo generuje on strumień informacji na temat odbiorców, pozwalając na ciągłe profilowanie bazy danych ${ }^{14}$.

Wprowadzenie wielokanałowej komunikacji z klientem nie jest czynnikiem gwarantującym sukces. Należy pamiętać, że omnichannel to rozwiązanie wymagające integralności, czyli spójnego komunikatu w postaci jednolitych cen w każdym kanale oraz ujednoliconej polityki obsługi klienta. Rzeczywistym skutkiem stosowania wszechkanałowości jest większa ekspozycja marki i ułatwiony dostęp do kontaktu z nią. Poprawne działania marketingowe prowadzone w ten sposób są bardziej spójne i są wyrazem tworzenia konsekwentnego wizerunku.

13 http://mamstartup.pl/e-commerce/8658/omnichannel-w-polskim-e-commerce-93sklepow-ze-sprzedaza wielokanalowa [dostęp 06.04.2017].

14 Tamże. 


\section{Podsumowanie - omnichannel jako trend czy poważny kierunek zmian}

Strategia wszechkanałowa jest konsekwencją transformacji handlu, jaką w ciągu ostatnich lat można obserwować. Następuje reorganizacja sposobów dostarczania produktów do odbiorców i dystrybucji towarów, co widać nie tylko na styku sprzedawcaklient, ale również producent-sprzedawca. Droga produktu w łańcuchu dostaw skraca się dzięki pominięciu pośredniczących detalistów. E-commerce sprawia, że opłacalne staje się inwestowanie producenta $\mathrm{w}$ drogę dotarcia bezpośrednio do konsumenta ${ }^{15}$.

Omnichannel należy rozpatrywać jako poważny kierunek zmian w obsłudze klienta, a nie tylko chwilowy trend. Wiąże się to ze zmianami technologicznymi, ale przede wszystkim z nowymi postawami w myśleniu zarówno kupujących, jak i sprzedających. Coraz większa wiedza oraz świadomość klientów, a co za tym idzie sprecyzowane wymagania, powodują wzrost popularności e-commerce. Daje to możliwość przyjęcia samoobsługowego podejścia w procesie zakupowym ${ }^{16}$.

$\mathrm{Z}$ punktu widzenia klienta skutkuje to poczuciem kontroli oraz pozornym wrażeniem szybszej realizacji transakcji - na proces składa się taka sama liczba podjętych decyzji, ale czas nadania zlecenia zależny jest wyłącznie od zachowania klienta. Zastosowanie wszechkanałowości jest dla sprzedawcy bardziej skomplikowanym procesem, wymagającym większego zaangażowania $\mathrm{w}$ wielu segmentach, tak by sprostać oczekiwaniom klienta.

Strategia omnichannel jest nietypowa z punktu widzenia przedsiębiorców. Skutki jej wprowadzenia nie są widoczne od razu, lecz dopiero w dłuższej perspektywie. Nie gwarantuje ona natychmiastowego zwiększenia przychodów, ale sprawia, że firma zyskuje nową jakość. Staje się bardziej nowoczesna i nastawiona na spełnienie wymagań klientów, których oczekiwania dotyczące szeroko rozumianego komfortu zakupowego stale rosną. Strategia ta jest niezbędna, by uzyskać wysoki poziom zadowolenia klienta i jest naturalną odpowiedzią na zmieniające się potrzeby rynku.

Wdrożenie omnichannel jest dla logistyki dużym wyzwaniem i choć bywa ona lekceważona $\mathrm{z}$ punktu widzenia klienta, $\mathrm{w}$ rzeczywistości stanowi fundament do wprowadzenia systemu wszechkanałowości. Sprawna i niezawodna dostawa towaru jest szczególnie ważna i ma bezpośredni wpływ na doświadczenia zakupowe klientów online, którzy w praktyce oceniają proces zakupu wyłącznie ograniczając się do doświadczeń związanych ze sferą dystrybucji, na którą składają się szybka i wygodna dostawa, jej koszt oraz przebieg całego procesu bez zakłóceń. Logistyka jest zarówno narzędziem, jak i zapleczem do sprawnego wykonywania usług, dlatego wymaga ciągłego udoskonalania jej procesów.

15 https://www.payu.pl/blog/omnichannel-multichannel-ktorego-podejscia-potrzebuje-twojsklep [dostęp 06.04.2017].

16 http://www.wirtualnemedia.pl/artykul/omnichannel-najwazniejszy-w-e-commerce-w2015-r-prognozy [dostęp 06.04.2017]. 


\section{Bibliografia}

Gajdzik B., Grzybowska K., (2013), SECI model and facilitation in change management in metallurgical enterprise, „Metalurgia”, vol. 52 (2), s. 275-289.

Hejduk I. K., Grudzewski W. M., (2008), Zarzqdzanie technologiami. Zaawansowane technologie i wyzwanie ich komercjalizacji, Wydawnictwo Difin, s. 350-379.

Mądry M., Mądry M., Saniuk S., (2012), Organizacje wirtualne jako sieć partnerstwa wspomagana technologiami informatycznymi.

\section{Źródta internetowe}

http://businesstraveller.pl/wp-content/uploads/2015/12/Starbucks_App-5_-860x573.jpg/ [dostęp 06.04.2017].

http://di.com.pl/wirtualne-sklepy-tesco-w-korei-poludniowej-39991/ [dostęp 06.04.2017].

http://gomobi.pl/news/sprzedawco-wdrazaj-w-modelu-omnichannel-strategie-i-przyklady/ [dostęp 06.04.2017].

http://i.telegraph.co.uk/multimedia/archive/02014/GD_Google0335_2014438c.jpg/ [dostęp 06.04.2017].

http://mamstartup.pl/e-commerce/8658/omnichannel-w-polskim-e-commerce-93-sklepow-

ze-sprzedaza-wielokanalowa/ [dostęp 06.04.2017].

http://marketerplus.pl/teksty/artykuly/kilka-slow-o-strategii-omnichannel/ [dostęp 06.04.2017].

http://nowymarketing.pl/a/10116,o-omnichannel-encyklopedia-marketingu [dostęp 06.04.2017].

http://www.benchmark.pl/testy_i_recenzje/omnichannel-nadzieja-na-konkurencyjnosc-

handlu-detalicznego.html/ [dostęp 06.04.2017].

http://www.dhl.com/content/dam/downloads/g0/about_us/logistics_insights/dhl_trendre-

port_omnichannel.pdf/ [dostęp 06.04.2017].

http://www.forbes.pl/g/i.aspx/0/500/forbes/635563962490714109.png/ [dostęp 06.04.2017].

http://www.getmemedia.com/public/ideas/Opp/12940/homeplus-5.jpg/ [dostęp 06.04.2017].

http://www.spidersweb.pl/2015/04/sklep-google-londyn.html/ [dostęp 06.04.2017].

http://www.wirtualnemedia.pl/artykul/omnichannel-najwazniejszy-w-e-commerce-w-2015-r-

prognozy/ [dostęp 06.04.2017].

https://retailnet.pl/2014/10/27/98094-zalando-otwiera-pierwszy-pop-store-w-polsce/ [dostęp 06.04.2017].

https://retailnet.pl/2015/05/28/12660-trzy-przeszkody-na-drodze-do-omnichannel-czy-wartopokonywac-je-samemu/ [dostęp 06.04.2017].

https://retailnet.pl/2015/12/22/15069-logisys-efektywna-logistyka-przy-sprzedazyomnichannel/ [dostęp 06.04.2017].

https://www.payu.pl/blog/omnichannel-multichannel-ktorego-podejscia-potrzebuje-twojsklep/ [dostęp 06.04.2017]. 